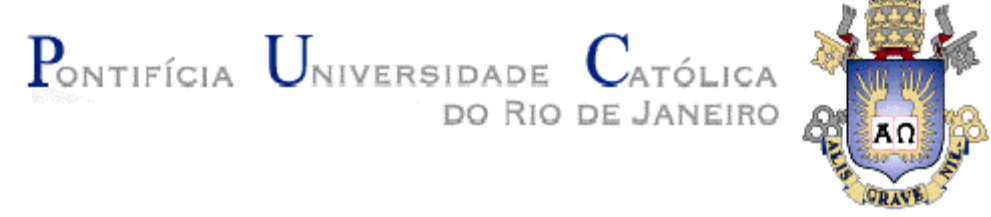

Denise Faith Brown

Autonomia e reciprocidade no desenvolvimento da identidade: Um olhar sobre a educação não formal

Dissertação apresentada como requisito parcial para obtenção do grau de Mestre pelo Programa de Pós-Graduação em Educação do Departamento de Educação da PUC-Rio.

Orientador: Profa. Tania Dauster

Rio de Janeiro

Abril de 2006 
Denise Faith Brown

\title{
Autonomia e reciprocidade no desenvolvimento da identidade: Um olhar sobre a educação não formal
}

\begin{abstract}
Dissertação apresentada como requisito parcial para obtenção do grau de Mestre pelo Programa de Pós-Graduação em Educação do Departamento de Educação do Centro de Teologia e Ciências Humanas da PUC-Rio. Aprovada pela Comissão Examinadora abaixo assinada.
\end{abstract}

Profa. Tania Dauster Orientadora

Departamento de Educação - PUC-Rio

Profa. Maria Ines Marcondes de Souza

Departamento de Educação - PUC-Rio

Prof. Pedro Benjamim C. Silva GarciaRita

UCP

Prof. Paulo Fernando C. de Andrade

Coordenador Setorial do Centro de

Teologia e Ciências Humanas

Rio de Janeiro, 17 de abril de 2006 
Todos os direitos reservados. É proibida a reprodução total ou parcial do trabalho sem autorização da universidade, doa autora e do orientador.

\section{Denise Faith Brown}

Denise Faith Brown graduou-se em Pedagogia na Universidade Federal Fluminense no ano de 2002. Ela é professora da Escola Britânica no Rio de Janeiro desde 1998 onde trabalha com educação infantil. Na mesma escola começou a coordenar a disciplina de artes no ano de 2005. Em 2006 concluiu o Curso de Mestrado em Educação na Puc-Rio apresentando a dissertação "Autonomia e reciprocidade no desenvolvimento da identidade: Um olhar sobre a educação não formal".

Ficha catalográfica

Brown, Denise Faith

Autonomia e reciprocidade no desenvolvimento da identidade : um olhar sobre a educação não formal / Denise Faith Brown ; orientador: Tânia Dauster. - Rio de Janeiro : PUC, Departamento de Educação, 2006.

106 f. ; $30 \mathrm{~cm}$

Dissertação (mestrado) - Pontifícia Universidade Católica do Rio de Janeiro, Departamento de Educação.

Inclui referências bibliográficas.

1. Educação - Teses. 2. Direitos humanos . 3. Ensino de História. 4. Educação em Direitos Humanos. 5. Democracia. 6. Cidadania. I. Dauster, Tania. II. Pontifícia Universidade Católica do Rio de Janeiro. Departamento de Educação. III. Título. 


\section{Agradecimentos}

Agradeço à Lygia Segalla por ter feito eu me apaixonar pela antropologia e Tânia Dauster por ter feito essa paixão virar amor.

Às professoras, Aparecida, Maria Inês, Isabel e Menga, com as quais tive aula durante o mestrado, eu agradeço pela excelente qualidade dos debates e por demonstrarem preocupação e carinho com cada um dos alunos.

Agradeço à Patrícia, secretária da pós-graduação na PUC, por toda ajuda em assuntos burocráticos e por ser sempre tão simpática.

Agradeço às amigas que fiz durante o mestrado, Patrícia, Ilana, Antônia e Lívia, por terem dado maior leveza a esse período tão intenso da minha vida.

Agradeço à instituição Se Essa Rua Fosse Minha por ter aberto suas portas a minha pesquisa e por ter possibilitado aprendizados importantes para esta dissertação e para a minha prática enquanto professora. Em especial, agradeço ao Cláudio, Ana Paula, Nego da Bahia, Marco Antônio, Rita, Queila e Fátima, com quem tive maior contato.

Por ter tornado possível o meu mestrado, me permitindo sair mais cedo do trabalho, e por acreditar em mim, agradeço à Carol.

Agradeço ao Paulo por estar do meu lado, dividindo comigo risadas, carinhos, discussões fomentadas sobre a educação e sobre a vida. Mas acima de tudo o agradeço por me ensinar tanto mais sobre o amor e sobre mim mesma.

Aos meus pais, que sempre me contaram histórias de sua ida a Marrocos, Europa, histórias de quando fizeram treinamento no meio da selva do México e do tempo que moramos em uma tribo indígena, eu agradeço por me ensinarem a ter o olhar de estrangeiro, e apreciar o outro, tão repleto de diferenças. Por isso e por todo amor que sempre me mostraram, eu sou mais do que grata. 
Agradeço a Sarah, minha sobrinha, por ter nascido e ter me dado tanta alegria no período final desta dissertação.

Ao Ulisses eu agradeço pelas vezes que leu minha dissertação, por ter me ajudado com pequenas coisas que eu não podia fazer por causa da correria da dissertação e por ter me encorajado.

À Deborah eu agradeço pelos trinta anos de amizade, por todas as lembranças de momentos que vivemos juntas e por continuar sempre ao meu lado.

Agradeço ao Pierre que, com seu encantamento, me ajudou a perceber a mágica e a simbologia presente no circo.

Agradeço à Elisa por ter debatido todos os textos da prova de admissão da PUC. Debates que me ajudaram a passar. Agradeço a ela também por ser tão Elisa e tão amiga.

Agradeço à Marina por ser doce e por ouvir meus dilemas de vida, de amor, de trabalho, sempre disposta a vir ao meu encontro quando preciso.

À Geórgia eu agradeço por ser um exemplo de pedagoga, completa em todos os sentidos. Agradeço também por ser amiga sincera.

Agradeço à Maria Gabriela por todos os momentos divertidos que passamos juntas, por deixar sua mãe ser um pouco minha também e por me apoiar sempre que precisei.

Ao Ricardo eu agradeço por me ajudar a enxergar o mundo de forma mais poética e irônica, dois extremos tão necessários à vida e tão necessários a mim.

Ao Vinícius eu agradeço por sempre ter feito parte das "meninas da pedagogia" mesmo não sendo menina e não tendo feito pedagogia. 
Agradeço à Ana Augusto por ser sensível, por saber meus dos sentimentos sem eu precisar dize-los e por dar conselhos sábios, além de tornar o dia-a-dia do trabalho tão mais agradável.

Agradeço à Sylvany e Michele por me ajudarem tanto com meus alunos no decorrer da minha dissertação e por contribuir para a paz e tranqüilidade que sinto em minha sala de aula.

Agradeço ao Flávio, à Raquel, ao Carlos e à Manuela por terem me acolhido e por fazer com que eu me sinta também amiga deles.

Ao Robson e à Marina eu agradeço por terem sido a minha primeira oportunidade de fazer uma etnografia e por terem se tornado meus amigos depois. 


\section{Resumo}

Brown, Denise Faith; Dauster, Tania. "Autonomia e reciprocidade no desenvolvimento da identidade: Um olhar sobre a educação não formal." Rio de Janeiro, 2006. 106p. Dissertação de Mestrado - Departamento de Educação, Pontifícia Universidade Católica do Rio de Janeiro.

Esta pesquisa tem como objetivo conhecer o trabalho desenvolvido pela instituicão "Se Essa Rua Fosse Minha" em relacão as identidades culturais. Dentro desta organização, o foco principal recaiu sobre o projeto "Dando Bola para a Vida". Este projeto tem como finalidade o trabalho de arte-educação, utilizando a metodologia do Circo Social, com as crianças e jovens do complexo do Cerro-Corá, localizado na Zona Sul do Rio de Janeiro. Foram analisadas duas categorias principais que surgiram da própria lógica do universo estudado: autonomia e reciprocidade. A partir destas categorias a relação dialética entre individuo e seu meio social se estabelece contribuindo para o desenvolvimento da identidade, do potencial de metamorfose e do alargamento do campo de possibilidades.

\section{Palavras-chave}

Identidade, autonomia, reciprocidade, potencial de metamorfose e campo de possibilidades. 


\section{Abstract}

Brown, Denise Faith; Dauster, Tania (Advisor). "Autonomia e reciprocidade no desenvolvimento da identidade: Um olhar sobre a educação não formal." Rio de Janeiro, 2006. 106p. MSc. Dissertation - Departamento de Educação, Pontifícia Universidade Católica do Rio de Janeiro.

The objective of this research is to understand the work developed by the institution "Se Essa Rua Fosse Minha" in relation to cultural identities. Within this organization the main focus was based on the project "Dando Bola para a Vida". This project works with the children from the community of Cerro-Corá, which is located in the South part of Rio de Janeiro. It uses an art-education perspective and applies the Social Circus method. Two categories, which arose from the focus group itself, were used: autonomy and reciprocity. Supported by these categories, the dialectics between individual and one's social surroundings is established and contributes to the development of the identity, of the potential of metamorphoses and of the broadening of the field of possibilities.

\section{Key words} possibilities.

Identity, autonomy, reciprocity, potential of metamorphosis, field of 


\section{Sumário}

1. Introdução 10

2. Ensaiando o espetáculo 19

3. Armando a lona 32

4. "Respeitável público" $\quad 40$

5. Aplausos finais - Conclusão

6. Referências Bibliográficas 82

$\begin{array}{ll}\text { Anexos } & 85\end{array}$

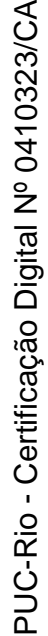

